\title{
Weapon of the Weak: One-Minute Speeches in the Israeli Parliament
}

\author{
Akirav Osnat ${ }^{1}$ \\ ${ }^{1}$ The Western Galilee College, Acre, Israel \\ Correspondence: Akirav Osnat, The Western Galilee College, Acre, Israel. E-mail: osnatak@bezeqint.net
}

Received: June 1, 2017

Accepted: June 15, 2017

Online Published: June 26, 2017

doi:10.5539/res.v9n3p75

URL: http://doi.org/10.5539/res.v9n3p75

\begin{abstract}
Position taking is an important legislative area that scholars have investigated extensively. Since one of the main roles of the opposition is to present an alternative to the government, the question is, how does the opposition establish its positions? To address this question, we analyze the use of One-Minute Speeches (OMSs) by opposition members in the Israeli parliament (the Knesset) during 2000-2013. There were four Knesset terms during these years, so we have the opportunity to study the opposition's behavior over a period of time. We decided to analyze OMSs because they are considered an easy tool to use and as such can be considered a weapon of the weak. The study uses mixed research methods, beginning with a statistical analysis (both at the legislator level and at the OMS level) and continuing with a content analysis of the speeches and the interviews conducted with members and leaders of the opposition. The statistical analysis shows that opposition members use OMSs more extensively than coalition members. Among the opposition members, we also found different behavior patterns based on nationality and seniority. In addition, the qualitative analysis of both the OMSs and the interviews shows that opposition members are active in two ways. First, they react to government-initiated proposals. Second, they raise topics for the Knesset's agenda, a move that the coalition generally does not appreciate. Third, members of the opposition consider OMSs an effective tool in that it allows them to create a relevant debate on current issues. Finally, ministers and other MKs often respond to the opposition's OMSs that are controversial and provoke debate. Thus, we conclude that the OMS is a weapon of the weak.
\end{abstract}

Keywords: coalition, Israel, One-Minute-Speeches, opposition, position taking, representatives

\section{Introduction}

The existence of the opposition is considered a cornerstone of democracy (e.g., Dahl, 1966; Helms, 2008a; Lawson, 1993). In its goal of replacing the government, the opposition, which is the weaker side, presents an alternative to its policies by criticizing them. The study of the opposition describes its composition, strength, definition, roles and effectiveness (e.g., Blondel, 1997; Dahl, 1966; Doring, 2001; King, 1976; Norton, 2008), but research about the opposition remains an inadequately explored area of political science (Mujica \& Sanchez-Cuenca, 2006). Furthermore, the research that does exist concentrates on the outcomes of the legislative process rather than on the behavior of the opposition as a political actor.

In this study, we focus on the opposition in Israel, specifically, the behavior of the individual opposition members using a parliamentary tool about which there is scant knowledge: One-Minute Speeches (OMSs). We maintain that the ease with which OMSs can be used make them an ideal weapon of the weak. Hence, we will explore their use by opposition members in the Israeli parliament (Knesset). We begin by describing the role of the opposition in democracy and then present our model of opposition activity as an illustration of this role. We then introduce the research about position taking in parliament and the use of light parliamentary tools such as OMSs. Our study investigates three questions. The first question is a descriptive one and asks, does the opposition use OMSs more frequently than coalition members? The second question considers the content of the OMSs by exploring how opposition members use them to take a position. The third question asks whether opposition members consider OMSs an effective parliamentary tool.

\section{Literature Review}

\subsection{The Definition and Role of the Opposition}

Scholars agree that the term "opposition" has several meanings and is used in different contexts (e.g., Barker, 1971; Dahl, 1971; Norton, 2008). They also note that any democracy actually hosts a plethora of oppositions (e.g., Blondel, 1997; Kaiser, 2008; King, 1976; Tuttnauer, 2013), and that it is a complex phenomenon and a 
nebulous concept (e.g., Barker, 1971; Norton, 2008). Hence, the attempt to define what constitutes the opposition is a highly contested matter (Morgenstern, Negri, \& Perez-Linan, 2008; Parry, 1997). In spite of these constraints, we will try to offer an acceptable definition for the opposition.

Kaiser (2008) suggested defining the opposition by two elements: their policy preferences and the institutional constraints under which they act. Regarding the policy preferences, Brack and Weinblum (2011) agreed that in fact political opposition is a "disagreement with the government or its politics, the political elite, or the political regime as a whole, expressed in the public sphere, by an organized actor through different modes of action" (p. 74). Regarding the institutional constraints, one of the indicators Tuttnauer (2013) suggested for evaluating parliamentary opposition was the strength of the parliamentary tools available to them.

In general, the opposition is defined as the parties not included in the executive cabinet. In this paper, we define the opposition in accordance with Kaiser's (2008) two elements: their policy preferences and their institutional constraints.

Thus, opposition parties seek one or more of the following: to become the ruling party, to become a partner in a coalition government, to influence policy, to protect and further the interests of their key constituencies, and to represent and give prominence to broader values and ideologies. The question we need to ask is, does the opposition have the strength to accomplish these goals?

Numerous studies have investigated the strength of the opposition in a variety of countries worldwide (e.g., Green-Pedersen \& Krogstrup, 2008; Helms, 2008b; Kaiser, 2008; Proksch \& Slapin, 2011; Salmond, 2004; Schrire, 2008; Tuttnauer, 2013; Wondwosen, 2009). However, Israel is one country in which there has been little research interest in the opposition (Akirav, Cox, \& McCubbins, 2010; Friedberg \& Hazan, 2009; Tuttanuer, 2013). Hence, one of our research goals is to expand the knowledge about the behavior of the opposition members in Israel.

The research about the strength of the opposition concentrates on understanding the procedures that allow the opposition to act and achieve its goals (Andeweg, De Winter, \& Muller, 2008; Blondel, 1997; Doring, 2001; Helms, 2008b; Kaiser, 2008; Tuttnauer, 2013). As Riker (1982) noted, institutional rules do not determine that a particular political outcome will occur. Instead, institutions can only change the likelihood that an event will happen. In this study, we look at the institutional rules in Israel that affect the opposition's ability to act and investigate how individual opposition members create a political outcome. Tuttanuer (2013) examined the parliamentary tools available to opposition members such as committees, parliamentary questions, motions for the agenda and legislation, but excluded OMSs as one of these tools. In discussing the four parliamentary tools available to Knesset members, Akirav (2014) classified them based on the degree of constraints involved in using them: heavy (legislation), medium (parliamentary questions and motions for the agenda and light (one-minute speeches). We maintain that as a light parliamentary tool, OMSs are important to opposition members, because they can use them more easily than other parliamentary mechanisms.

Legislators have a variety of parliamentary tools-legislative and non-legislative - so it is no surprise that most studies have concentrated on legislation (e.g., Cox \& McCubbins, 2005; Mayhew, 1991; Olson, 1994; Stratmann, 2000; Tsebelis, 2002). Mujica and Sanchez-Cuenca (2006) expanded this approach by analyzing the content of the bills of opposition members.

Special attention has been paid to budgetary legislation. Falco-Gimeno and Jurado (2011) showed that when the opposition's support is required to pass the budget, it will push for deficits if it has sufficient strength and is contesting a fragile government. Akirav, Cox and McCubbins (2010) found that in the Knesset the opposition parties' roll rates on exceptional bills such as the budget are higher than their roll rates on ordinary bills. Green-Pedersen and Krogstrup (2008) claimed that in the competition for voters, legislative bills are one way to signal one's priorities to the public.

Only a few scholars have examined the use of parliamentary questions or questioning time as a means by which the opposition can oversee the government (e.g., Proksch \& Slapin, 2011; Saalfeld, 2011; Salmond, 2004). Even fewer have investigated OMSs as a tool for opposition members to take a position (Hall, 2002; Morris, 2001; Rocca, 2007). As we can see, parliamentary questions and OMSs are considered less relevant and effective tools for opposition members in overseeing the government and taking a position on public policy issues. However, we maintain that these specific light tools can be very effective in challenging the government from unexpected directions.

The conclusions of scholars about the strength of the opposition vary. Parliamentary opposition depends on indirect opportunities to affect parliamentary decisions in two areas: committees and plenary debates (Auel \& 
Raunio, 2014; Kaiser, 2008). Brauninger and Deubus (2009) argued that despite the clear distinction between the government and the opposition in parliamentary democracies, there is indeed room to accommodate agenda setting by the opposition. Furthermore, activities take place across the government-opposition divide. Nevertheless, opposition and bipartisan agenda setting is rare. It is neither absent nor spurious, but related to the allocation of power and the intensity of ideological conflict both within and between the coalition government and parliament. For example, the parliamentary opposition in Japan is constrained, but it still finds some room to maneuver and may influence legislative politics (Inoguchi, 2008).

Morgenstern et al. (2008) examined the size and shape of the opposition in 18 countries in Latin America, finding great diversity in the size and cohesion of the opposition. In their study, four distinctive patterns of opposition emerged: resistance - in which the opposition is small but remains united, divided government in which a united opposition controls at least one of the legislative chambers, feeble opposition - in which the opposition is a small and divided contingent with limited veto ability, and disarray - in which the opposition, albeit large, may be weak because it is very divided, and the president may be able to offer selected incentives to particular parties or individuals to create an ad-hoc coalition (Morgenstern et al., 2008, pp. 166-167). Tuttnauer (2013) examined the size and unity of the opposition in Israel from the establishment of the state in 1948 until 2013. He found that the ratio between the size of the opposition and its unity (its structural strength) in Israel was 0.13 , while the average of other western democracies is 0.22 . The institutional strength, which he determined by assessing the committee system, showed that in Israel the opposition has less influence than oppositions in democracies worldwide.

The opposition and individual opposition parties are significant players in overseeing the government and challenging it publicly, but are less effective in affecting the outcomes of public policy (Norton, 2008). For example, Hazama (1996) found that in Turkey, a constitutional review provides opportunities for the parliamentary opposition to compensate for its legislative weakness. Similarly, Andeweg, De Winter and Muller (2008) concluded that while there is an opposition in Austria, Belgium and the Netherlands, it is not very active or competitive.

In light of these studies, one may question why the existence of an opposition is considered a cornerstone of democracy when studies show that in most countries, it is weak and does not play its role effectively. Scholars offer several explanations for this conundrum. These explanations are similar to Morgenstern and colleagues' (2008) four distinctive patterns of opposition. First, splits in the opposition may be one of the explanations for it weakness. When the opposition is concentrated in a single party, in the short-term it may be rewarded by the electorate, but in the long run, it will need to deal with the debt it incurs for this reward (Falco-Gimeno \& Jurado, 2011; Tuttnauer, 2013).

Tuttnauer (2013) found that parliamentary democracies contain two types of oppositions. The first form is a large and united opposition that has little influence on the government. The second form is a small and divided opposition that compensates for these shortcomings by participating in significant decision-making and legislation. The Israeli opposition appears to embody the worst of both worlds. It is small and faction-ridden, and the parliamentary tools available to the Israeli opposition are limited and ineffectual.

Second, ideology and fragmentation may hobble the opposition, particularly if it contains more than one party. Furthermore, even if the opposition consists of a single party, there may be ideological and political variances that weaken and divide the opposition (e.g., Falco-Gimeno \& Jurado, 2011; Flemming \& Damggard, 2008). Third, the opposition may suffer from its role in the legislative process, both on the floor and within committee debates. What are the procedures that enable them to be significant actors and when do they not make a difference (Flemming \& Damggard, 2008; Friedberg \& Hazan, 2009; Schrire, 2008; Tuttnauer, 2013)? Fourth, the existence of a minority government may hamper the role of the opposition. Flemming and Damggard (2008) found that while parliamentary opposition is influential under a minority government, during the last two decades government and opposition parties have become more likely to engage in policy-making together.

All of these studies are about opposition at the institutional level, but the challenges are even more demanding when we look at the individual level. Hence, we ask, do the opposition members in the Israeli parliament behave in accordance with these ideas? By analyzing their use of light parliamentary tools such as OMSs, we hope to answer this question.

\subsection{Position Taking in Parliament}

Legislators have multiple roles including enacting legislation, and engaging in oversight, representation, policy-making and position taking (Blomgren \& Rozenberg, 2012; Fenno, 1978; Koger, 2003; Mayhew, 1974; Saalfeld \& Muller, 1997). Their multiple roles operate in two formal arenas of parliament: on the floor and in 
committees. Needless to say, these two areas are related to one another. There are three major characteristics of floor time. First, all of the legislators are supposed to be present during the debates, but in some countries it is not mandatory. Second, all of the debates are open to the public, who are welcome to attend and watch the debates and votes. Finally, the proceedings on the floor are broadcast directly on television. Thus, visibility on the floor is an essential part of parliamentary life (Sheafer \& Wolfsfeld, 2004).

Martin and Vanberg (2008) focused on floor debates for several reasons. First, the floor debates are vehicles through which the representatives can publicly justify their positions on the policies they are about to adopt. Second, legislative debates provide a good picture of the other rhetorical strategies of the representatives. Previous studies have shown that representatives use their speeches on the floor to advertise their positions to their supporters (Maltzman \& Sigelman, 1996; Mayhew, 1974). The parliamentary debate provides the opposition parties with a bully pulpit from which they can criticize the policies of the government (Martin \& Vanberg, 2008). Representatives make systematic use of the opportunities provided by floor debates to communicate with their voters (Hill \& Hurley, 2002; Maltzman \& Sigelman, 1996).

Any political institution has its procedures, which define the opportunities and the limitations available to its members in their daily work. In light of the limited time and resources that legislators have, do opposition members use OMSs more frequently than coalition members, and if so, in what manner? Scholars have suggested that those who tend to use OMS are individualistic and institutionally disadvantaged, ideologically extreme, members of a minority party, electorally insecure, and rank low in terms of tenure, party identification and party rank (Maltzman \& Sigelman, 1996; Morris, 2001; Rocca, 2007).

Members of Congress tend to use OMSs because they are viewed as a safety value for MCs who feel left out of the decision-making process (Maltzman \& Sigelman, 1996). Furthermore, if taking a position might be rewarding, MCs will do so hoping that the voters will translate it into electoral gains for them. The same trend is evident in the MCs' sponsoring of legislation. Studies have shown that they invest a great deal of time convincing colleagues to sponsor their legislation (Fowler, 2006; Koger, 2003). Even though sponsoring bills has no formal effect on the legislative process, the sponsorship enables legislators to take a position (Campbell, 1982; Woon, 2008). Hence, we can say that legislators use a variety of parliamentary tools in order to take a position.

The OMS is rooted in three important legislative areas: position taking, legislative organization and legislative participation. The unconstrained nature of the OMS facilitates position taking. In addition, the motivations for using OMSs shed light on why legislators designed the institution the way they did (legislative organization) and on legislative participation.

\section{Hypotheses}

Given the findings about the strength of the opposition and the use of OMSs, we posit:

H1: Opposition members use one-minute speeches more frequently than coalition members.

Minorities by definition have a weaker position in parliaments. Today, the Arab community in Israel perceives itself as a national minority and increasingly demands to be recognized as such (Frisch, 2011; Ghanem \& Mustafa, 2011). Furthermore, despite the heterogeneity of Arab society, Arabs in Israel are a singular minority with a shared collective identity that differs from that of Israeli Jews as well as from the Palestinians outside of Israel. Indeed, they are "Palestinians in Israel" (Peleg \& Waxman, 2011). They want both individual equality and national equality with Jewish Israelis. In addition, they are not prepared to wait until the Israeli-Palestinian conflict is over for these demands to be met (Ghanem \& Mustafa, 2011). The vast majority of the Arab minority in Israel wants to coexist with Israeli Jews, remain citizens of the State of Israel and overwhelmingly prefer peaceful protest over violence to create change (Frisch, 2011; Peleg \& Waxman, 2011). The majority of Israel's Arab citizens still work within the system. They seem to be cognizant both of the economic and democratic benefits derived from citizenship in the Jewish state despite recent legislative efforts to constrain the Arab political elite (Frisch, 2011). Given their position as part of the permanent opposition (Boyne et al., 2009), we would expect them to use the parliamentary tool with the least constraints more extensively than members of the majority group. Therefore, we posit:

H2: Opposition members who are Arabs use OMSs more frequently than Jewish members of the coalition.

Opposition members who have seniority have probably held positions in the past such as committee chairs, deputy ministers or ministers. As members of the opposition without a position, they may choose to act meaningfully, decide to go underground and be silent or use any parliamentary tool available to them in order to be heard with the goal of paving their way toward a future executive position. Junior opposition members who have little experience may be disappointed by the drop in their status to that of backbenchers. They are still 
learning about the effectiveness and efficiency of the parliamentary tools available to them. Senior opposition members already know that of the mechanisms available to them, the one-minute speech is the easiest to use. Therefore, we maintain that:

H3: Opposition members who have seniority use OMSs more extensively than coalition members who are junior MKs.

Hypotheses 4 and 5 are about the content of the speeches. We test them using material from our in-depth interviews with legislators. Hence, they are qualitative research hypotheses.

H4: The content of the opposition's OMSs focuses on oversight of the government.

H5: Opposition members prefer OMSs as a tool for raising topics of concern to them.

\subsection{One-Minute Speeches in the Israeli Parliament}

Since 2000, the year OMSs were established in the Israeli parliament, five elections have taken place and four prime ministers have been in office. Hence, it is interesting to explore and understand the use of a new parliamentary tool, the OMS, which has few limitations and offers MKs the opportunity to speak out against government policy.

\subsection{Procedures Governing OMSs (Note 1)}

Most parliaments, such as those in the UK, Scotland, Finland, Japan and New Zealand, do not use OMSs. Only five elected bodies have adopted it: the US House of Representatives, the European Parliament and the parliaments of Australia, Canada and Israel. A comparison of the procedures governing OMSs in these five legislatures yields several insights. First, OMSs provide one of the few opportunities for non-legislative debate, where debate is almost always confined to the pending legislative business. Second, the recognition of the right to give a one-minute speech is the prerogative of the Speaker. Third, in the US House one-minute speeches are not provided for in the rules of the House, while in the Israeli parliament, the Australian parliament and the European Parliament they are. Fourth, there are set periods when OMSs can be given. Finally, each Member can give only one speech each legislative day. In sum, we can see that the opportunities OMSs give the Members in all five legislatures are similar. The speeches are not about legislation. The speech is initiated by a Member at a given time and lasts for a specified period. In the light of these restrictions, how do opposition MKs use OMSs?

As mentioned above, Riker (1982) notes that institutional rules do not determine that a particular political outcome will occur. Instead, institutions can only change the likelihood that an event will happen. What are the institutional rules governing the opposition's ability to act in the Israeli parliament?

\subsection{Procedures Governing OMSs in Israel}

The first thirty minutes on Monday and Tuesday in which there are no votes of no confidence begin with one-minute speeches. Every MK (including ministers and deputy ministers who are MKs) may speak. In order to do so, he/she needs to be on the floor and push the vote button to register. Therefore, MKs have a weekly opportunity to address the voters and tell them about their thoughts, wishes and activities without factional quotas or the Speaker's approval. Hence, OMSs are a comprehensive indicator of the opposition MKs' initiative, because its use is entirely in the hands of the legislator.

Several institutional arrangements allow opposition members in the Israeli parliament to fulfill all of the roles of the opposition such as taking positions and criticizing the government, as well as introducing motions of no confidence, debates about the budget law, parliamentary questions, motions for the agenda and working in committees. In some cases, there are major restrictions on their ability to act. In other cases, the opposition's members have the ability to fulfill their role. Furthermore, it is interesting to note that until 2000 the opposition leader in the Israeli parliament did not have any formal status. Prime ministers used to update the opposition's leaders frequently about central issues. In 2000, the Knesset amended the law regarding the position of the opposition's leader. Since then, the prime minister must update the opposition's leader at least once a month (Chapter F, article 13). The opposition's leader may speak on the floor after the prime minister's speech (Chapter F, article 14), participates in official ceremonies (Chapter F, article 15) and receives a salary and all of the benefits similar to those of the ministers (Chapter F, article 16).

\section{Method}

In order to answer the three research questions-does the opposition use one-minute speeches more frequently than coalition members, how does the opposition use one-minute speeches and do opposition members consider one-minute speeches effective-we analyzed 5,953 OMSs made by Knesset members in the Israeli parliament during the years 2000-2013. Four Knesset terms (the 15th, 16th, 17th and 18th) are included between these years. 
Given that in every Knesset term we have several coalitions whose composition varies, this range of years allows us to examine the behavior of the opposition over a period of time. Specifically, each coalition contains 5 to 10 parties in the opposition. Note that the position of the Israeli opposition is not established in the political culture. Most Israeli coalitions created a very small, divided opposition. Nevertheless, several norms have been established. The heads of several committees are from the opposition, one of the Knesset representatives for the committee that appoints judges is from the opposition, some of the Speakers' deputies are from the opposition, and the head of the opposition usually speaks after the prime minister on special occasions.

Table 1 describes the various parliamentary tools available to parliament members based on the tool's primary purpose, its use by factions versus individual parliament members and its ease of use. As the table illustrates, the one-minute speech is an easy tool to use and is in the hands of the parliament member. Hence, we expect disadvantaged parliament members, mostly opposition members, to use it more than other parliament members. Furthermore, a quick search of YouTube yields more than 2,000 short films with the title "one-minute speeches". Therefore, parliament members can upload their one-minute speeches to YouTube and share their thoughts with a large audience with minimum effort.

Table 1. Mapping parliamentary tools

\begin{tabular}{cccc}
\hline Parliamentary tool & The tool's primary purpose & $\begin{array}{c}\text { Faction versus individual } \\
\text { parliament member }\end{array}$ & Ease of use \\
\hline Legislation & Public policy & Faction & Difficult \\
Motion for the agenda & Setting the agenda & Faction & Medium \\
Parliamentary questions & Government oversight & Individual parliament member & Medium \\
One-minute speeches & Self-expression and representation & Individual parliament member & Easy \\
\hline
\end{tabular}

We decided to analyze OMSs because they are considered an easy tool to use. Indeed, we can describe OMSs as weapon for the weak because they offer short-term benefits, such as allowing a legislator to take a position on a topic of special interest to him or her, and long-term benefits, such as demonstrating ongoing participation in legislative procedures. The study uses mixed research methods. First, we conduct a statistical analysis of the OMSs, once at the OMS level and once at the legislator level. The latter allows us to analyze the internal (nationality) and external (seniority and opposition/coalition affiliation) explanatory variables of the legislators' behavior. Second, we also analyze the speeches and interviews conducted with members and leaders of the opposition (Note 2) with the goal of identifying words and phrases that criticize the government, its policy or a specific action of the government.

\section{Results and Discussion}

\subsection{The Use of OMSs at the Legislators' Level}

Table 2 presents the distribution of OMSs throughout the four Knesset terms. We can see an increase in their use between the first Knesset term that adopted the OMS and the second term. Then there was a decline from the second term to the third term followed by another increase. The range is similar between the third and the fourth terms, but different from the first and the second term. We can see that the 16th Knesset is the exception both in the average number of OMSs and their range.

Table 2. Average OMSs by Knesset terms

\begin{tabular}{ccccc}
\hline & 15th Knesset & 16th Knesset & 17th Knesset & 18th Knesset \\
\hline Average Speeches & 14.74 & 21 & 13.3 & 17.18 \\
Range & $1-62$ & $1-77$ & $1-57$ & $1-59$ \\
\hline
\end{tabular}

To determine whether the differences between the Knesset terms are significant, we ran a one-way ANOVA analysis and found that the average speeches between Knesset terms were significant $(\mathrm{F}=4.107$, sig=0.007). Looking deeper into the variance (Post-Hoc Multiple Comparisons-Tukey test), we found that the 16th Knesset had more OMSs than the 15th Knesset, and the 16th Knesset had more than the 17th Knesset. The 16th Knesset 
had the largest number of opposition members (52) compared to the other Knesset terms and the smallest number of coalition members (68) compared to the other Knesset terms. Hence, we would expect to see that the opposition members were more active based on their large number.

Furthermore, in Table 3 we can see the opposition's use of OMSs compared to that of the coalition. Since the first day of OMSs in the Knesset (January 2000), in every term the opposition delivered on average $65 \%$ of the OMSs, while the coalition delivered $35 \%$ of them. Thus, the data clearly demonstrate the extensive use of OMSs by the opposition MKs, regardless of whether the opposition is strong or weak. Furthermore, this tendency accords with the literature both on light parliamentary tools such as parliamentary questions (Akirav, 2011; Saalfeld, 2011; Wiberg, 1994) and one-minute speeches (e.g., Maltzman \& Sigelman, 1996; Morris, 2001; Rocca, 2007). This result supports Hypothesis 1, demonstrating that opposition members do use OMSs more frequently than members of the coalition.

Table 3. The use of OMSs by the opposition versus the coalition

\begin{tabular}{ccccc}
\hline & 15th Knesset & 16th Knesset & 17th Knesset & 18th Knesset \\
\hline Opposition & $61 \%$ & $32 \%$ & $60 \%$ & $65 \%$ \\
Coalition & $35 \%$ & $33 \%$ & $38 \%$ & $31 \%$ \\
\hline
\end{tabular}

To determine which explanatory variables (nationality, gender, seniority or coalition/opposition affiliation) were relevant to the use of OMSs, we ran an independent samples t-test. We found that just two variables were significant: opposition/coalition affiliation and nationality. Furthermore, note that the two variables overlap because most of the Arab MKs belong to opposition parties. Tables 4 and 5 present the findings.

Table 4. The use of OMSs by opposition/coalition affiliation

\begin{tabular}{ccccc} 
& 15th Knesset & 16th Knesset & 17th Knesset & 18th Knesset \\
\hline T Value & 2.917 & & 3.071 & 2.348 \\
Sig & 0.000 & Not sig & 0.003 & 0.021 \\
\hline
\end{tabular}

Table 4 demonstrates that except for the 16th Knesset, opposition members used OMSs much more frequently than coalition members. As mentioned previously, the 16th Knesset had the largest number of opposition members and the smallest number of coalition members. Given the first fact, the opposition clearly felt emboldened to raise issues both on the floor and in the committees. Second, given the small size of the coalition, every member was needed to retain control over the government.

Table 5. The use of OMSs by nationality

\begin{tabular}{ccccc}
\hline & 15th Knesset & 16th Knesset & 17th Knesset & 18th Knesset \\
\hline T Value & 4.668 & 4.978 & & 2.667 \\
Sig & 0.000 & 0.000 & Not sig & 0.000 \\
\hline
\end{tabular}

Table 5 shows us that except for the 17th Knesset, Arab MKs used OMSs much more frequently than Jewish MKs. Given their weak position in the Knesset, their choice of the weapon of the weak is not surprising. Since we noted that the variables overlap and are therefore multi-collinear, we used a multivariable model to determine the effect of each of the variables for all four Knesset terms (stepwise regression). Three variables were significant $(\mathrm{F}=21.543$, $\mathrm{Sig}=0.00)$; nationality-Arab MKs use OMSs more than Jewish MKs, opposition/coalition affiliation - opposition members use OMSs more than coalition members, seniority - MKs who have served two terms or more in the Knesset use OMSs more than first-term MKs. These three variables explain $15.4 \%$ of the variance in the use of one-minute speeches by Israeli legislators.

These findings confirm Hypotheses 2 and 3. Opposition members who are Arabs use OMSs more frequently than Jewish members of the coalition, and opposition members who have seniority use OMSs more extensively 
than coalition members who are junior MKs. In order to strengthen the findings we analyzed the speeches at the OMS level, meaning each OMS rather than each legislator was the unit of analysis.

\subsection{The Use of OMSs at the OMS Level}

The literature about the strength of the opposition talks about its composition. We were interested in investigating whether specific aspects of the opposition in Israel are more significant than others in determining the opposition's use of OMSs. Hence, we ran crosstab procedures looking at Phi and Cramer's V in order to determine the strength of the use of OMSs. The factors we examined were nationality and seniority.

\subsection{Nationality}

We wondered whether nationality was one of the major factors in understanding the opposition's extensive use of OMSs. Hypothesis 2 proposed that opposition members who are Arabs use OMSs more frequently than Jewish members of the coalition. As mentioned previously, in Israel most of the Arab MKs are part of the opposition. In addition, their number in the Knesset suffers from under-representation compared to their share in the general population. Furthermore, since the establishment of Israel in 1948 and up until now, no Arab party has taken part in the coalition. Therefore, Arab MKs can be considered a permanent part of the opposition in Israel.

Table 6. The connection between coalition/opposition membership and nationality with regard to the use of OMSs

\begin{tabular}{ccccc}
\hline & 15th Knesset & 16th Knesset & 17th Knesset & 18th Knesset \\
\hline Phi & 0.408 & 0.327 & 0.176 & 0.301 \\
Sig & 0.000 & 0.000 & 0.000 & 0.000 \\
\hline
\end{tabular}

From Table 6 we can see that opposition members who are Arabs use OMSs more frequently than Jewish members of the coalition. These findings are similar to those in previous studies both regarding nationality (e.g., Morris, 2001; Rocca, 2007) and Arab MKs (Akirav, 2010; Schueftan, 2011) and support Hypothesis 2.

\subsection{Seniority}

Seniority is another variable that scholars have studied extensively, especially regarding legislative effectiveness, legislative entrepreneurship and sponsorship of legislation (Anderson, Box-Steffensmeier, \& Sinclair-Chapman, 2003; Frantzich, 1979; Garand \& Burke, 2006; Mayhew, 2000; Moore \& Thomas, 1990; Schiller, 1995). To determine seniority, we divided the MKs into two categories: first term MKs and those who are in their second term or greater. Based on the literature, Hypothesis 3 posited that opposition members who have seniority use OMSs more extensively than coalition members who are junior MKs.

Table 7. The connection between coalition/opposition membership and seniority with regard to the use of OMSs

\begin{tabular}{ccccc}
\hline & 15th Knesset & 16th Knesset & 17th Knesset & 18th Knesset \\
\hline Phi & 0.122 & 0.212 & 0.466 & 0.253 \\
Sig & 0.000 & 0.000 & 0.000 & 0.000 \\
\hline
\end{tabular}

From Table 7 we can see that opposition members who have seniority use OMSs more extensively than coalition members who are junior MKs. These findings accord with the literature; senior representatives are more active than their junior peers (e.g., Akirav, 2010; Frantzich, 1979; Morris, 2001; Moore \& Thomas, 1990).

Based on previous studies, our findings are not surprising. Representatives who are at a disadvantage, such as members of the opposition, tend to use light procedural tools more extensively than other representatives. In addition, we see that within the opposition, factors such as seniority and nationality strengthen the use of OMSs.

In sum, as previous studies have established, the Israeli opposition makes extensive use of light procedural tools such as the OMS - the weapon of the weak. Furthermore, national minorities' opposition members, as well as those who have greater seniority, use OMSs even more extensively than their coalition colleagues. Kaiser (2008) identified two elements of the opposition: their policy preferences and the institutional constraints under which 
they act. With regard to the second part of the definition, the Israeli opposition faces various institutional constraints, so it makes extensive use of the OMS because it is a tool that is relatively unconstrained. Our last two hypotheses addressed the question of how opposition members use OMSs - for oversight of the government and to take a stand on a position of concern to them. To test Hypothesis 5 about the use of OMSs as an oversight tool, we analyzed the content of the speeches.

\subsection{The Content of the Speeches}

We analyzed the content of all 5,953 OMSs. Two assistants coded the material separately, beginning with a sample of 500 OMSs. First, each assistant looked for key words indicative of the tone of the speeches (positive, negative or neutral toward the government), who the speeches refer to (criticizing the government as a whole, criticizing a specific minister, criticizing the prime minister) and the subject of the speeches, as well as policy issues, service issues involving the efforts of representatives to secure particular benefits for individuals or groups in their voters, and allocation issues, meaning the representative's efforts to obtain benefits for his or her voters. Then, they coded each speech based on its major words, so we could classify it based on whether it criticized the government/minister/deputy minister/prime minister and on whether the topic revolved around policy, service or allocation. After we determined that their coding was reliable, they coded the rest of the speeches.

The content analysis yielded three main categories: the subject of the speeches, the tone of the speeches (positive, negative or neutral toward the government), and who the speeches refer to (the government in general, a specific party in the coalition, a specific minister, a general case or a specific case).

\subsection{The Subject of the Speeches}

Most studies about political speeches or political agenda setting map the content of speeches by subject such as the economy, the military, social welfare, education, and health care. In this study, we relied on a combined model of Pitkin (1967) and Eulau and Karps (1977). They defined three components of representation: policy where the target is the great public issues that agitate the political process, service which involves the efforts of representatives to secure particular benefits for individuals or groups in their constituency, and allocation which refers to the representative's efforts to obtain benefits for his or her constituency. Do opposition members invest more time in speeches about policy, hence criticizing the government, or speeches about their voters?

Based on the content analysis, we made several findings. First, opposition members use OMSs to criticize the government's policy on a variety of subjects (Arab members more about Israeli policy about the Palestinians, Jewish left wing opposition members more about social issues). Second, opposition members do not neglect their voters and do refer to specific issues that concern them (both service and allocation components). Third, opposition members regard OMSs as almost the only parliamentary tool that allows them to speak up and be seen and heard.

\subsection{The Tone of the Speeches}

We categorized the tone of the speeches as positive, negative or neutral toward the government (e.g., Lombard, Snyder-Duch, \& Bracken, 2002; Sheafer, 2007) by searching for words that praised the government or criticized it. Most of the speeches were critical in tone regardless of the nationality, gender, ideology or seniority of the opposition members. This finding is not surprising. What is surprising is that there is a battle between opposition members who use more severe words against the government's policy. Few speeches praised the government, but even those that did include some criticism, as if using the carrot and stick system. We did not find any speeches that were neutral in tone. As mentioned above, this finding is not surprising, as we expect opposition members to criticize the government's policy.

\subsection{Who the Speeches Refer to}

We also categorized the object of the speeches into six topics: the coalition in general, the government in general, a specific party from the coalition, a specific minister, a general case or a specific case. We found that the majority of the speeches referred to the government. The rest of the speeches were spread out among the other five topics with no specific pattern.

Based on the preliminary interviews we conducted with opposition members, it appears that OMSs give them the opportunity to set their agenda with minimum constraints and maximum exposure to their voters. Although the OMS is short, it can be very precise, sharp and hurtful to the government.

The quantitative part of the research showed us that opposition member in the Israeli parliament use OMSs more frequently than coalition members. Furthermore, within the opposition we can see that Arab members, senior 
members and members of left wing ideological parties use OMSs more frequently than other MKs. Looking at the qualitative part of the research, we can see that opposition members consider OMSs a significant tool for taking a position, and criticizing the government and the coalition parties. These findings support Hypothesis 4 about the use of OMSs as a tool for overseeing the government.

When analyzing the content of the speeches, two more interesting results emerged: MKs' reactions to the speeches (which are not allowed in the procedures) and ministers' reactions to the speeches (which are allowed in the procedures). Table 8 shows that in most speeches other MKs do not respond, but there are a few in which they do, particularly with regard to controversial issues such as the future of the territories, the economic policy of the government, and the government's solutions to the problem of poverty.

Table 8. MKs and ministers respond to OMSs

\begin{tabular}{ccc}
\hline & Other MKs respond & Ministers respond \\
\hline No & $5521(92.7 \%)$ & $4673(78.5 \%)$ \\
Yes & $432(7.3 \%)$ & $1280(21.5)$ \\
\hline
\end{tabular}

Ministers respond more to OMSs than other MKs, usually to reiterate the government's policy on controversial issues. One can argue that such a result is expected, because the procedures allow the ministers to react to the speeches. The interesting result is the reaction of other MKs who are not allowed to react but still do so. Using $\chi^{2}$ analysis we found that both other MKs and ministers respond to OMSs that deal with controversial issues. Furthermore, when we ran a $\chi^{2}$ analysis for the connection between the ministers responding and opposition/coalition OMSs we found that the ministers usually responded to the OMSs of the opposition $\left(\chi^{2}=13.375\right.$, sig $\left.=0.000\right)$. Thus, even though we can characterize the OMS as the weapon of the weak, it can provoke heated debate.

The final hypothesis, H5, claimed that opposition members prefer OMSs as an effective tool for taking a stand on an issue of concern to them. In order to test this hypothesis, we interviewed opposition members and asked them two questions: Do you consider the use of OMSs effective? For what purpose do you use an OMS (private issues, general issues, to make a point)?

The effectiveness of OMSs. Members of the opposition considered OMS an effective tool in the sense that it allowed them to initiate a debate on timely topics of concern to them. For example, one opposition member used OMSs to criticize the speech of the host in the memorial ceremony for the Carmel Forest tragedy (Note 3). The opposition members used satire in their OMSs to drive home their criticism (Note 4). Their OMSs prompted many responses on national TV and in the newspapers and the digital media. Indeed, one of the opposition members described the OMS as the Knesset's Twitter. He also said that because the other parliamentary tools have lost their relevancy, the sound bite nature of the OMS and the quick debate (Note 5) have become the tools that allow MKs to make sharp and pointed comments on current issues. He noted that the length of the OMS is its main advantage, allowing MKs to express themselves in a short, focused manner.

The use of OMSs. The MKs indicated that they use OMSs in several ways. First, it is a useful tool for talking about a current issue. Second, they use it to continue the discussion on a topic raised in the morning meeting of a committee that did not receive the attention it should have. Third, the OMS is useful for raising an issue that the public has brought to the MKs' attention and about which they want the MKs' assistance. Fourth, when used in combination with other parliamentary tools, the OMS can help MKs set the agenda. Finally, there are times when several MKs separately and without coordination with each other raise the same issue on the same day using the OMS. When such an event occurs, the issue receives a great deal of attention. Based both on the content analysis of the OMSs and the interviews with opposition members, we can see that they use OMSs for position taking, thereby confirming Hypothesis 5.

\section{Conclusions}

Opposition is an inseparable part of modern democracy. As such, we must investigate its strength, composition, role and effectiveness. The current research addresses this challenge by examining the opposition in a country that has been neglected in previous research (Israel) using a parliamentary tool that has also received scant attention in legislative studies (OMSs). Using mixed research methods helps us draw a comprehensive picture of how opposition members in the Israeli parliament use OMSs. The study is also innovative in two other ways. It is the first such study to investigate the activities of opposition members through their use of parliamentary tools 
rather than legislation, parliamentary questions or committee work. Second, it extends our knowledge about the use of OMSs and the attitude of legislators to them.

The neglect of OMSs in the research must change. Even though the OMS exists in only five legislatures worldwide, it can be an important light parliamentary tool that opposition members and other legislators can use to take a position on issues that matter to them. Furthermore, this use of mixed research methods allows us to see the same phenomenon from different points of view, thereby improving our understanding about how the opposition takes a position on various issues. Future research should compare the countries that use OMSs, looking for similarities and differences. Finally, given Norton's (2008) claim that the opposition has a limited effect on the outcomes of public policy, researchers should establish methods for defining and examining the effectiveness of OMSs. One possibility to investigate is the idea that legislators use the OMS as a trial balloon that paves the way for more expansive attempts to influence the outcomes of public policy, allowing those in the opposition to turn this weapon of the weak to their advantage.

\section{References}

Akirav, O. (2010). Candidate selection and a crowded parliament: The Israeli Knesset 1988-2006. Journal of Legislative Studies, 16(1), 96-120. https://doi.org/10.1080/13572330903542142

Akirav, O. (2014).What do representatives produce? Work profile of representatives. Party Politics, 1-11.

Akirav, O., Cox, G. W., \& McCubbins, M. D. (2010). Agenda control in the Israeli Knesset during Ariel Sharon's second government. Journal of Legislative Studies, 16(2), 251-267. https://doi.org/10.1080/13572331003740149

Anderson, W., Box-Steffensmeier, J., \& Sinclair-Chapman, V. (2003). The key of legislative success in the U.S. House of Representatives. Legislative Studies Quarterly, 28(3), 357-386. https://doi.org/10.3162/036298003X200926

Andeweg, B. R., De Winter, L., \& Muller, C. W. (2008). Parliamentary opposition in post-consociational democracies: Austria, Belgium and the Netherlands. The Journal of Legislative Studies, 14(1-2), 77-112. https://doi.org/10.1080/13572330801921034

Arian, A. (2005). Politics in Israel: The second republic (2nd ed.). CQ Press.

Auel, K., \& Raunio, T. (2014). Debates the State of the Union? Comparing parliamentary debates on EU issues in Finland, France, Germany and the United Kingdom. Journal of Legislative Studies, 20(1), 13-28. https://doi.org/10.1080/13572334.2013.871482

Barker, R. (1971). Introduction. In R. Barker (Ed.), Studies in opposition. London: Macmillan. https://doi.org/10.1007/978-1-349-01158-2_1

Blondel, J. (1997). Political opposition in the contemporary world. Government and Opposition, 32(4), 462-486. https://doi.org/10.1111/j.1477-7053.1997.tb00441.x

Boyne, G. A., James, O., John, P., \& Petrovsky, N. (2009). Democracy and government performance: Holding incumbents accountable in English local governments. The Journal of Politics, 71(4), 1273-1284. https://doi.org/10.1017/S0022381609990089

Brack, N., \& Weinblum, S. (2011). Political opposition: Toward a renewed research agenda. Interdisciplinary Political Studies, 1(1), 69-79.

Brauninger, T., \& Deubus, M. (2009). Legislative agenda-setting in parliamentary democracies. European Journal of Political Research, 48, 804-839. https://doi.org/10.1111/j.1475-6765.2009.00850.x

Cox, G. W., \& McCubbins, M. D. (2005). Setting the agenda. Cambridge: Cambridge University Press. https://doi.org/10.1017/CBO9780511791123

Dahl, R. (1971). Polyarchy: Participation and opposition. New Haven: Yale University Press.

Dahl, R. (Ed.). (1966). Political oppositions in Western democracies. New Haven: Yale University Press.

Doring, H. (2001). Parliamentary agenda control and legislative outcomes in Western Europe. Legislative Studies Quarterly, 26, 145-166. https://doi.org/10.2307/440407

Eulau, H., \& Karps, P. D. (1977). The puzzle of representation: Specifying components of responsiveness. Legislative Studies Quarterly, 2, 233-254. https://doi.org/10.2307/439340

Falco-Gimeno, A., \& Jurado, I. (2011). Minority governments and budget deficits: The role of the opposition. European Journal of Political Economy, 27, 554-565. https://doi.org/10.1016/j.ejpoleco.2011.03.002 
Flemming, J. C., \& Damggard, E. (2008). Parliamentary opposition under minority parliamentarism: Scandinavia. The Journal of Legislative Studies, 14(1-2), 46-76. https://doi.org/10.1080/13572330801920937

Frantzich, S. (1979). Who makes our laws? The legislative effectiveness of members of the U.S. Congress. Legislative Studies Quarterly, 4, 409-428. https://doi.org/10.2307/439582

Friedberg, C., \& Hazan, Y. R. (2009). Legislative oversight of the executive branch in Israel: Current status and proposed reform. Jerusalem: Israel Democracy Institute (Hebrew).

Frisch, H. (2011). Israel security and its Arab citizens. New York: Cambridge University Press. https://doi.org/10.1017/CBO9780511820649

Garand, J. C., \& Burke, K. M. (2006). Legislative activity and the 1994 Republican takeover: Exploring changing patterns of sponsorship and cosponsorship in the U.S. House. American Politics Research, 34, 159-188. https://doi.org/10.1177/1532673X05284415

Ghanem, A., \& Mustafa, M. (2011). The Palestinians in Israel: The challenge of the indigenous group politics in the "Jewish state". Journal of Muslim Minority Affairs, 31(2), 177-196. https://doi.org/10.1080/13602004.2011.583504

Green-Pedersen, C., \& Krogstrup, J. (2008). Immigration as a political issue in Denmark and Sweden. European Journal of Political Research, 47, 610-634. https://doi.org/10.1111/j.1475-6765.2008.00777.x

Hall, T. E. (2002). Live bureaucrats and dead public servants: How people in government are discussed on the floor of the House. Public Administration Review, 62(2), 242-251. https://doi.org/10.1111/0033-3352.00174

Hazama, Y. (1996). Constitutional review and the parliamentary opposition in Turkey. The Developing Economies, 34(3), 316-338. https://doi.org/10.1111/j.1746-1049.1996.tb00742.x

Hazan, Y. R. (1999). Constituency interests without constituencies: The geographical impact of candidate selection on party organization and legislative behavior in the 14th Israeli Knesset, 1996-1999. Political Geography, 18(7), 791-811. https://doi.org/10.1016/S0962-6298(99)00028-1

Helms, L. (2008a). Studying parliamentary opposition in old and new democracies: Issues and perspectives. The Journal of Legislative Studies, 14(1-2), 6-19. https://doi.org/10.1080/13572330801920788

Helms, L. (2008b). Parliamentary opposition and its alternatives in a transnational regime: The European Union in perspective. The Journal of Legislative Studies, 12(1-2), 212-235. https://doi.org/10.1080/13572330801921208

Hill, K. Q., \& Hurley, P. A. (2002). Symbolic speeches in the U.S. Senate and their representational implications. Journal of Politics, 64, 231-291. https://doi.org/10.1111/1468-2508.00125

Inoguchi, T. (2008). Parliamentary opposition under (post-) one-party rule: Japan. The Journal of Legislative Studies, 14(1-2), 113-132. https://doi.org/10.1080/13572330801921067

Kaiser, A. (2008). Parliamentary opposition in Westminster democracies: Britain, Canada, Australia and New Zealand. The Journal of Legislative Studies, 14(1-2), 20-45. https://doi.org/10.1080/13572330801920887

King, A. (1976). Modes of executive-legislative relations: Great Britain, France and West Germany. Legislative Studies Quarterly, 1(1), 11-34. https://doi.org/10.2307/439626

Lawson, S. (1993). Conceptual issues in the comparative study of regime change and democratization. Comparative Politics, 25, 183-195. https://doi.org/10.2307/422351

Lombard, M., Snyder-Duch, J., \& Bracken, C. C. (2002). Content analysis in mass communication: Assessment and reporting of intercoder reliability. Human Communication Research, 28, 587-604. https://doi.org/10.1111/j.1468-2958.2002.tb00826.x

Maltzman, F., \& Sigelman, L. (1996). The politics of talk: Unconstrained floor time in the US House of Representatives. Journal of Politics, 58, 819-830. https://doi.org/10.2307/2960448

Martin, W. L., \& Vanberg, G. (2008). Coalition government and political communication. Political Research Quarterly, 61(3), 502-516. https://doi.org/10.1177/1065912907308348

Mayhew, D. R. (1974). Congress: The electoral connection. New Haven: Yale University Press.

Mayhew, D. R. (1991). Divided we govern. New Haven: Yale University Press.

Mayhew, D. R. (2000). America's Congress. New Haven: Yale University Press. 
Moore, M. K., \& Thomas, S. (1990). Explaining legislative success in the U.S. Senate: The role of the majority and minority parties. Western Political Quarterly, 44, 959-970.

Morgenstern, S., Negri, J. J., \& Perez-Linan, A. (2008). Parliamentary opposition in non-parliamentary regimes: Latin America. The Journal of Legislative Studies, 12(1-2), 160-189. https://doi.org/10.1080/13572330801921166

Morris, J. S. (2001). Reexamining the politics of talk: Partisan rhetoric in the 104th House. Legislative Studies Quarterly, 26(1), 101-121. https://doi.org/10.2307/440405

Mujica, A., \& Sanchez Cuenca, I. (2006). Consensus and parliamentary opposition: The case of Spain. Government and Opposition, 41(1), 86-108. https://doi.org/10.1111/j.1477-7053.2006.00172.x

Norton, P. (2008). Making sense of opposition. The Journal of Legislative Studies, 12(1-2), 236-250. https://doi.org/10.1080/13572330801921257

Olson, D. M. (1994). Democratic legislative institutions. New York: M.E. Sharpe.

Parry, G. (1997). Opposition questions. Government and Opposition, 32(4), 457-461. https://doi.org/10.1111/j.1477-7053.1997.tb00440.x

Peleg, I., \& Waxman, D. (2011). Israel's Palestinians, The conflict within. Cambridge: Cambridge University Press. https://doi.org/10.1017/CBO9780511852022

Pitkin, H. F. (1967). The concept of representation. Berkeley, CA: University of California Press.

Polletta, F. (1998). Legacies and liabilities of an insurgent past. Social Science History, 22(4), 479-512. https://doi.org/10.1017/S0145553200017922

Proksch, S., \& Slapin, J. B. (2011). Parliamentary questions and oversight in the European Union. European Journal of Political Science, 50, 53-79. https://doi.org/10.1111/j.1475-6765.2010.01919.x

Riker, H. W. (1982). The two-party system and Duverger's Law: An essay on the history of political science. American Political Science Review, 76(4), 753-766. https://doi.org/10.1017/S0003055400189580

Rocca, M. S. (2007). Non-legislative debate in the U.S House of Representatives. American Politics Research, 35(4), 489-505. https://doi.org/10.1177/1532673X07300233

Saalfeld, T. (2011). Parliamentary questions as instruments of substantive representation: Visible minorities in the UK House of Commons, 2005-2010. The Journal of Legislative Studies, 17(3), 271-289. https://doi.org/10.1080/13572334.2011.595121

Salmond, R. (2004). Grabbing government by the throat: Question time and leadership in New Zealand's parliamentary opposition. Political Science, 56(2), 75-90. https://doi.org/10.1177/003231870405600209

Sartori, G. (1966). Opposition and control: Problems and prospects. Government and Opposition, 1(2), 149-154. https://doi.org/10.1111/j.1477-7053.1966.tb00368.x

Schiller, W. J. (1995). Senators as political entrepreneurs: Using bill sponsorship to shape legislative agendas. American Journal of Political Science, 39, 186-203. https://doi.org/10.2307/2111763

Schrire, A. R. (2008). Parliamentary opposition after apartheid: South Africa. The Journal of Legislative Studies, 12(1-2), 190-211. https://doi.org/10.1080/13572330801921190

Schueftan, D. (2011). Palestinians in Israel: The Arab minority and the Jewish state. Kinneret, Zmora-Bitan, Dvir Publishing, Israel. (Hebrew).

Sheafer, T. (2007). How to evaluate it: The role of story-evaluative tone in agenda setting and priming. Journal of Communication, 57, 21-39. https://doi.org/10.1111/j.0021-9916.2007.00327.x

Sheafer, T., \& Wolfsfeld, G. (2004). Production assets, news opportunities, and publicity for legislators: A study of Israeli Knesset members. Legislative Studies Quarterly, 29, 611-630. https://doi.org/10.3162/036298004X201320

Stratmann, T. (2000). Congressional voting over legislative careers: Shifting positions and changing constraints. American Political Science Review, 94(3), 665-676. https://doi.org/10.2307/2585838

Tsebelis, G. (2002). Veto players: How political institutions work. Princeton: Princeton University Press. https://doi.org/10.1515/9781400831456

Tuttnauer, O. (2013). The role of the opposition in the Knesset. In Policy paper 98. The Israel Democracy Institute, Jerusalem. (Hebrew). 
Wiberg, M. (Ed.). (1994). Parliamentary controlin the Nordic countries. The Finnish Political Science Association.

Wondwosen, T. (2009). Opposition parties and the politics of the opposition in Africa: A critical analysis. World Academy of Science, Engineering and Technology, 55, 812-826.

\section{Notes}

Note 1. This analysis is based on Part D, Chapter two, Article 33a of the Rules of Procedure of the Knesset and on Mulvihill (1999). One-Minute Speeches: Current House Practices. CRS Report for Congress.

Note 2. We emailed a sample of 20 current opposition MKs, asking them if we could interview them about their activities as opposition members. Twelve of them agreed to our request and were interviewed.

Note 3. The Mount Carmel forest fire (The Carmel Disaster) was a deadly forest fire that started on Mount Carmel in northern Israel, just south of Haifa. The fire began at about 11:00 AM local time on 2 December 2010, and spread quickly, consuming much of the Mediterranean forest covering the region. The fire claimed 44 lives, making it the deadliest in Israeli history. The dead were mostly Israel Prison Service officer cadets, as well as three senior police officers, among them the chief of Haifa's police. More than 17,000 people were evacuated, including several villages in the vicinity of the fire, and there was considerable property and environmental damage.

Note 4. https://www.youtube.com/watch?v=4JU8oUtK1Jo

Note 5. "The Knesset Member is entitled to make a motion for a quick debate in one of the Knesset committees ... A motion that has been submitted by 13:00 on Sunday shall be deliberated by the Presidium in the same week ... A committee, to which a topic has been referred for a quick debate, shall begin the debate within ten days from the day on which the Knesset Presidium took its decision" (Rule of Procedures, Chapter D, article 60).

\section{Copyrights}

Copyright for this article is retained by the author(s), with first publication rights granted to the journal.

This is an open-access article distributed under the terms and conditions of the Creative Commons Attribution license (http://creativecommons.org/licenses/by/4.0/). 